\title{
Article
}

http://dx.doi.org/10.11646/phytotaxa.175.5.1

\section{Erysimum hezarense, a new species and Rhammatophyllum gaudanense, a new record of Brassicaceae from Iran}

\author{
HAMID MOAZZENI ${ }^{1}$, SHAHIN ZARRE ${ }^{1}$, MOSTAFA ASSADI ${ }^{2}$, MOHAMMAD REZA JOHARCHI ${ }^{3} \&$ DMITRY \\ A. GERMAN ${ }^{4}$ \\ 1. Center of Excellence in Phylogeny of Living Organisms, and Department of Plant Sciences, School of Biology, College of Science, \\ University of Tehran, P.O. Box 14155-6455, Tehran, Iran \\ 2. Research Institute of Forests and Rangelands, PO Box 13185-116, Tehran, Iran \\ 3. Department of Botany, Research Center for Plant Science, Ferdowsi University of Mashhad, Mashhad, Iran \\ 4. Centre for Organismal Studies, Heidelberg University, Im Neuenheimer Feld 345, 69120 Heidelberg, Germany; \& South-Siberian \\ Botanical Garden, Altai State University, Lenina str. 61, 656049 Barnaul, Russia \\ *Corresponding author: hmoazzeni@ut.ac.ir
}

\begin{abstract}
Two Brassicaceae novelties are reported from Iran. Erysimum hezarense (Erysimeae) is described and illustrated as a newly discovered species. It resembles E. subulatum, E. laxiflorum and E. iraqense but can be readily distinguished by the indumentum of stem, leaves and pedicels; bicolor petals; and number of flowers on the main inflorescence. It is also separated geographically being restricted to Hezar mts. (prov. Kerman, South Iran) where none of the related species occurs. Because of the very limited distribution and high risk of its habit destruction, inclusion of $E$. hezarense into IUCN Red List with a status vulnerable (VU) is proposed. Besides, Rhammatophyllum gaudanense (Euclidieae) is reported from NE Iran representing the first record of the genus for the country. Contrary, the previous record of $R$. gaudanense from Afghanistan is considered doubtful and not confirmed. Detailed morphological description, illustration and synonymy of $R$. gaudanense is provided along with the key differences from the closely related taxa. Distribution maps for both E. hezarense and $R$. gaudanense are given.
\end{abstract}

Key words: Cruciferae, Erysimeae, Euclidieae, Iran, new species, new record.

\section{Intoduction}

During a field trip to S Iran as well as the treatment of herbarium material of several herbaria in the context of the $\mathrm{PhD}$ project of the first author, some novelties have been detected, two of which are reported herein. The first is a new species of Erysimum Linnaeus (1753: 660), E. hezarense, collected from the south of Iran, province of Kerman. The second novelty is the first record of both Rhammatophyllum gaudanense (Litvinov 1902: 33) Al-Shehbaz \& O. Appel (2002: 3) and the genus Rhammatophyllum O.E. Schulz (1933b: 190) from Iran.

\section{Taxonomic treatment}

\section{Erysimum}

Erysimum is one of the largest genera of the Brassicaceae (Cruciferae). It is well known for its taxonomic complexity due to tremendously overlapping morphological characters, and its diversity estimations range from 150 (Zhou et al. 2001, Al-Shehbaz 2010) to 290-350 species (Polatschek \& Snogerup 2002). The diversity of Erysimum is centered in SW Asia and Eastern Mediterranean where new species are still being described (e. g., Polatschek 2008, 2011; Moazzeni et al., 2014).

According to the Flora Iranica account (Polatschek \& Rechinger 1968) and subsequent additions (Polatschek 2008, 2010, 2011; German 2014), 31 Erysimum species occur in Iran. One more species described herein was discovered during the botanical investigation of Hezar (Hezar-Lalezar) mountains which formerly had been rarely studied by botanists. Taking this novelty into account, 32 Erysimum species are recorded at the moment from Iran, seven of which are endemics. 


\section{Acknowledgments}

We would like to thank A. Pirani, Y. Ajani and the staff of FUMH for their assistance in field surveys. Nona Karimzadeh is gratefully acknowledged for the illustrations. We are grateful to Jalil Noroozi for preparing the geographical map. We also thank the directors and the curators of the herbaria cited for the loan and permission to study the specimens.

\section{References}

Ajani, Y. \& Ajani, M. (2008) A new species of Ferula (Umbelliferae) from Southern Iran. Edinburgh Journal of Botany 65: $425-431$. http://dx.doi.org/10.1017/s0960428608005052

Al-Shehbaz, I.A. (2010) Erysimum Linnaeus. In: Flora of North America editorial committee (Eds.) Flora of North America north of Mexico. Vol. 7. Oxford University Press, New York, pp. 534-545.

Al-Shehbaz, I.A. (2012) A generic and tribal synopsis of the Brassicaceae (Cruciferae). Taxon 61: 931-954.

Al-Shehbaz, I.A. \& Appel, O. (2002) A synopsis of the Central Asian Rhammatophyllum (Brassicaceae). Novon 12: 1-4. http://dx.doi.org/10.2307/3393228

Appel, O. \& Al-Shehbaz, I.A. (2003) Cruciferae. In: Kubitzki, K. (Ed.) Families and Genera of Vascular Plants. Springer-Verlag, Berlin, Heidelberg, 5: 75-174.

Boissier, P.E. (1842) Plantae aucherianae orientales enumeratae, cum novarum specierum descriptione. Annales des Sciences Naturelles: Botanique, 2 sér., 17: 45-90, 150-205, 381-390.

Botschantzev, V.P. (1952) Plantae novae ex Asia Media. Botanicheskie Materialy Gerbariya Instituta Botaniki Akademii Nauk UzSSR (Notulae Systematicae ex Herbario Instituti Botanici Academiae Scientarum Uzbekistanicae) 13: 3-18.

Botschantzev, V.P. (1966) De Cruciferis notae criticae, 5. Novosti Sistematiki Vysshikh Rastenii (Novitates Systematicae Plantarum Vascularium) 3: 122-139.

Botschantzev, V.P. (1987) De genere Prionotrichon Botsch. et Vved. (Cruciferae - Arabideae). Novosti Sistematiki Vysshikh Rastenii (Novitates Systematicae Plantarum Vascularium) 24: 96-100.

Botschantzev, V.P. \& Vvedensky, A.I. (1948) Cruciferae novae ex Asia Media. Botanicheskie Materialy Gerbariya Instituta Botaniki i Zoologii Akademii Nauk UzSSR (Notulae Systematicae ex Herbario Instituti Botanici et Zoologici Academiae Scientarum Uzbekistanicae) 12: 3-12.

Gay, J.É. (1842) Erysimorum quorumdam novorum diagnoses simulque Erysimi muralis descriptionem praemittit monographiam. Bethune \& Plon, Paris, 16 pp.

German, D.A. (2007) On some critical taxa of Altai Cruciferae. Problems of Botany of South Siberia and Mongolia / Proceedings of the $6^{\text {th }}$ International Scientific-Practical Conference (Barnaul, October 25-28, 2007). AzBuka, Barnaul, pp. 17-25.

German D.A. (2014) Notes on taxonomy of Erysimum (Erysimeae, Cruciferae) of Russia and adjacent states. I. Erysimum collinum and Erysimum hajastanicum. Turczaninowia 17, 1: 10-32.

http://dx.doi.org/10.14258/turczaninowia.17.1.3

German, D.A., Shmakov, A.I., Zhang, X.-C., Chen, W.-L., Smirnov, S.V., Xie L., Kamelin, R.V. \& Wang, J. (2006) Some new floristic findings in Xinjiang, China. Acta Phytotaxonomica Sinica 44: 598-603.

German, D.A., Friesen, N., Neuffer, B., Al-Shehbaz, I.A. \& Hurka, H. (2009) Contribution to ITS phylogeny of the Brassicaceae, with a special reference to some Asian taxa. Plant Systematics and Evolution 283: 33-56. http://dx.doi.org/10.1007/s00606-009-0213-5

IUCN Standards and Petitions Subcommittee. (2013) Guidelines for Using the IUCN Red List Categories and Criteria. Version 10.1. Prepared by the Standards and Petitions Subcommittee. Downloadable from http://www.iucnredlist.org/documents/RedListGuidelines.pdf (accessed: 20 October 2013).

Kamelin, R.V. (2002) Notes on Cruciferae of Asia. Genus Rhammatophyllum and its affinity. Botanicheskii Zhurnal 87, 12: 97-109.

Karelin, G.S. \& Kirilov, I.P. (1842) Enumeratio plantarum in desertis Songoriae orientalis et in jugo summarum alpium Alatau anno 1841 collectarum. Byulleten Moskovskogo Obstchestva Ispytatelei Pripody (Bulletin de la Société Impériale des Naturalistes de Moscou) 15: 129-180, 321-453, 503-542.

Kilian, N., Djavadi, S.B. \& Eskandari, M. (2012) Two new mountainous species of Lactuca (Cichorieae, Asteraceae) from Iran, one presenting a new, possibly myrmecochorous achene variant. PhytoKeys 11: 61-77. http://dx.doi.org/10.3897/phytokeys.11.2563

Linnaeus, C. (1753) Species Plantarum. Vol. 2. Impensis Laurentii Salvii, Holmiae, 1200 pp.

Litvinov, D.I. (1902) Plantae Turcomaniae (Transcaspiae). Trudy Botanicheskogo muzeia Imperatorskoi Akademii nauk (Travaux de Musée botanique de l'Académie Impériale des Scientes de St.-Pétersburg) 1:23-46. 
Moazzeni, H., Zarre, S., Pfiel, B.E., Bertrand, Y.J.K., German, D.A., Al-Shehbaz, I.A., Mummenhoff, K. \& Oxelman, B. (2014) Phylogenetic perspectives on diversification and character evolution in the species-rich genus Erysimum (Erysimeae; Brassicaceae) based on a densely sampled ITS approach. Botanical Journal of the Linnean Society 175: 497-522.

http://dx.doi.org/10.1111/boj.12184

Nabiev, M.M. (1974) Prionotrichon Botsch. et Vved. In: Vvedensky, A.I. \& Pachomova, M.G. (Eds.) Opredelitel Rastenii Srednei Azii (Conspectus florae Asiae Mediae) Vol. 4. Editio Academiae Scientarum UzSSR, Tashkent, pp. 88-89.

Nikitin, V.V. \& Geldikhanov, A.M. (1988) A key for plants of Turkmenistan. Science Press, Leningrad, 680 pp.

Noroozi, J., Ajani, Y. \& Nordenstam, B. (2010) A new annual species of Senecio (Compositae- Senecioneae) from subnival zone of southern Iran with comments on phytogeographical aspects of the area. Compositae Newsletter 48: 43-62.

Podlech, D. (2012) Checklist of flowering plants of Afghanistan. Ludwig-Maximilians Universität München [http://www.sysbot.biologie. uni-muenchen.de/de/personen/podlech/flowering_plants_afghanistan.pdf]

Podlech, D., Zarre, S. \& Maassoumi, A.A. (2001) Astragalus III. In: Rechinger, K.H. (Ed.) Flora Iraninca, Vol. 178. Avesa, Akademische Verlagsgesellschaft, Salzburg, Austria.

Polatschek, A. (2008) Erysimum (Brassicaeae): 15 neue Arten aus Europa, N-Afrika und Asien. Annalen des Naturhistorischen Museums in Wien - Serie B 109: 147-165.

Polatschek, A. (2010) Revision der Gattung Erysimum (Cruciferae): Teil 1: Russland, die Nachfolgestaaten der USSR (excl. Georgien, Armenien, Azerbaidzan), China, Indien, Pakistan, Japan und Korea. Annalen des Naturhistorischen Museums in Wien - Serie B 111: $181-275$

Polatschek, A. (2011) Revision der Gattung Erysimum (Cruciferae), Teil 2: Georgien, Armenien, Azerbaidzan, Türkei, Syrien, Libanon, Israel, Jordanien, Irak, Iran, Afghanistan. Annalen des Naturhistorischen Museums in Wien - Serie B 112: 369-497.

Polatschek, A. \& Rechinger, K.H. (1968) Erysimum. In: Rechinger, K.H. (Ed.) Flora Iranica. Vol. 57. Akademische Druck- u. Verlagsanstalt, Graz, pp. 285-303, 350-353.

Polatschek, A. \& Snogerup, S. (2002) Erysimum. In: Strid, A. \& Tan, K. (Eds.) Flora Hellenica. Vol. 2. Koeltz Scientific Books, Königstein, pp. 130-152.

Rechinger, K.H. (1954) Cruciferae novae Afghanicae. Anzeiger. Abteilung II. Österreichische Akademie der Wissenschaften, MathematischNaturwissenschaftliche Klasse 91: 58-64.

Rechinger, K.H. (1968) Koeiea. In: Rechinger, K.H. (Ed.) Flora Iranica. Vol. 57. Akademische Druck- u. Verlagsanstalt, Graz, pp. 247$248,349$.

Rotov, R.A. (1984) Prionotrichon gaudanense (Litv.) Botsch. In: Borodin, A.M., Bannikov, A.G. \& Sokolov, B.E. (Eds.) Red Book of USSR: Rare and endangered species of animals and plants. Ed. 2. Vol. 2. Lesnaya promyshlennost', Moscow, p. 119.

Schulz, O.E. (1933a) Eine neue Cruciferen-Gattung in Mittelasien. Notizblatt des Botanischen Gartens und Museums zu Berlin-Dahlem 11: $872-873$. http://dx.doi.org/10.2307/3994640

Schulz, O.E. (1933b) Über verschiedene Cruciferen. Repertorium Specierum Novarum Regni Vegetabilis 33: $183-191$. http://dx.doi.org/10.1002/fedr.19330330807

Warwick, S.I., Sauder, C.A., Al-Shehbaz, I.A. \& Jacquemoud, F. (2007) Phylogenetic relationships in the tribes Anchonieae, Chorisporeae, Euclidieae, and Hesperideae (Brassicaceae) based on nuclear ribosomal ITS DNA sequences. Annals of the Missouri Botanical Garden 94: 56-78.

http://dx.doi.org/10.3417/0026-6493(2007)94[56:pritta]2.0.co;2

Zhou, T.Y., Lou, L.L., Yang, G., Dorofeyev, V.I. \& Al-Shehbaz, I.A. (2001) Erysimum Linnaeus. In: Wu, Z.Y. \& Raven, P.H. (Eds.). Flora of China. Vol. 8. Science Press, Beijing \& Missouri Botanical Garden Press, St. Louis, pp. 163-169. 